\title{
PENGARUH KONSENTRASI KALSIUM KLORIDA (CaCl2) DAN LAMA PERENDAMAN TERHADAP UMUR SIMPAN DAN PEMATANGAN BUAH MANGGA (Mangifera indica L) Cv. MANALAGI
}

\author{
Lia Andriani ${ }^{1}$, Yahdi ${ }^{2}$ dan Lutvia Krismayanti ${ }^{3}$ \\ 1 Jurusan Pendidikan IPA Biologi FITK IAIN Mataram \\ ${ }^{2,3}$ Dosen Jurusan Pendidikan IPA Biologi FITK IAIN Mataram
}

\begin{abstract}
Abstrak
Penelitian ini bertujuan untuk melihat pengaruh konsentrasi kalsium klorida $(\mathrm{CaCl} 2)$ dan lama perendaman terhadap umur simpan dan pematangan buah mangga (Mangifera indica L) Cv. Manalagi. Penelitian ini mengunakan Rancangan Acak Lengkap (RAL) pola factorial terdiri atas 2 faktor, yaitu faktor A (konsentrasi kalsum klorida dengan taraf a1 konsentrasi 5\%, a2 $10 \%$ dan a3 20\%) dan faktor B (lama perendaman dengan taraf b1 lama perendaman 1 menit, b2 15 menit, b3 30 menit, dan b4 60 menit) dengan 12 kombinasi perlakuan dan 3 ulangan. Data yang diperoleh tersebut dianalisis menggunakan ANAVA. Hasil analisis data tersebut menunjukkan bahwa $\mathrm{F}$ hitung $\leq \mathrm{F}$ tabel sehingga $\mathrm{Ha}$ ditolak artinya konsentrasi kalsium klorida dan lama perendaman tidak berpengaruh terhadap umur simpan dan pematangan buah mangga (Mangifera indica L) Cv. Manalagi, karena disebabkan oleh beberapa faktor diantaranya suhu, waktu pemetikan dan tingkat kematangan buah yang digunakan.
\end{abstract}

Kata Kunci: Konsentrasi, kalsium klorida, buah mangga (Mangifera indica L) Cv. Manalagi. 


\section{PENDAHULUAN}

Buah mangga merupakan salah satu buah tropis yang sangat digemari oleh masyarakat karena rasanya manis dan memiliki aroma yang khas. Ada beberapa varietas mangga komersial diantaranya yakni mangga manalagi. Buah mangga manalagi adalah buah berukuran sedang dengan kulit buah yang masih muda hijau dan memiliki rasa yang sangat menggiurkan. Buah manalagi yang segar mengandung nilai gizi yang tinggi sebagai sumber kesehatan bagi manusia. Di samping sebagai bahan pangan untuk kebutuhan pribadi, buah mangga manalagi juga dapat menjadi salah satu peluang usaha yang mempunyai nilai ekonomis cukup tinggi.

Berdasarkan hasil observasi yang dilaksanakan oleh peneliti di Pasar Pagesangan Mataram pada tanggal 12 November 2015, banyak ditemukan buah mangga manalagi yang membusuk (rusak) sebelum dikonsumsi. Kondisi ini menimbulkan permasalahan penurunan produktivitas buah dan merosotnya harga buah manalagi di pasaran sehingga merugikan para pedagang buah. Selain itu, di Kawasan Dusun Pohdodol tempat penulis tinggal, banyak ditemukan pula buah mangga manalagi yang jatuh dari pohonnya dalam keadaan busuk. Kerusakan pada buah dapat menyebabkan penurunan kualitas dan nilai ekonomi buah tersebut, karena buah lebih disukai untuk dikonsumsi dalam keadaan segar.

Buah mangga manalagi termasuk buah klimaterik, yaitu buah yang mengalami kenaikan respirasi setelah dipanen sehingga buah dapat matang sempurna dan menuju ke proses penuaan yang secara tidak langsung menjadi sebab utama kemunduran atau kerusakannya. Buah mangga manalagi memiliki kandungan air yang tinggi, oleh karena itu buah mangga manalagi tergolong komoditas hortikultura yang sangat mudah rusak. Kurangnya pengetahuan para petani hortikultura dan pedagang buah mengenai alternatif yang dapat diterapkan untuk menjaga kualitas buah menyebabkan tingkat kerusakannya semakin tinggi, sementara kualitasnya semakin rendah. Oleh karena itu, upaya 
untuk memperlambat kerusakannya perlu dilakukan agar buah masih dalam kondisi yang baik hingga siap dikonsumsi.

Salah satu alternatif perbaikan kualitas buah manggamanalagi untuk memperpanjang umur simpan yakni dengan memberikan bahan kimia secara eksogen, yaitu pemberian kalsium klorida $(\mathrm{CaCl} 2)$. Kalsium Klorida $(\mathrm{CaCl} 2)$ merupakan Bahan Tambahan Pangan (BTP) yang mempunyai toksisitas sangat rendah, berdasarkan data (kimia, biokimia, toksikologi dan data lainnya) dan telah mendapat Izin dari Badan Pengawas Obat dan Makanan Republik Indonesia Nomor 24 Tahun 2013 tentang Batas Maksimum Penggunaan Bahan Tambahan Pangan. Batas maksimum penggunaan kalsium klorida (CaCl2) yakni $350 \mathrm{~g} / \mathrm{kg}$.

Potensi kalsium klorida $(\mathrm{CaCl} 2)$ sebagai bahan untuk menghambat laju pematangan buah tidak hanya dapat dimanfaatkan pada buah mangga, namun dapat dimanfaatkan pula pada beberapa jenis buah lainnya, seperti buah naga, pepaya, anggurdan buah tomat. Adapun laporan hasil penelitian sebelumnya menyatakan bahwa kalsium klorida $(\mathrm{CaCl} 2)$ dapat memperpanjang umur simpan buah naga super merahdengan cara menghambat proses pematangannya. Selain dapat menghambat laju pematangan buah, kalsium klorida $(\mathrm{CaCl} 2)$ juga dapat meningkatkan kandungan vitamin $\mathrm{C}$ pada buah anggur dan buah tomat.

Perendaman buah mangga dalam larutan kalsium klorida (CaCl2) dapat menghambat kelunakan daging buah dan memperpanjang umur simpan buah. Kalsium mempunyai sifat mudah larut dalam air, dengan adanya kalsium klorida $(\mathrm{CaCl} 2)$ dalam larutan, maka ion $\mathrm{Ca}^{2+}$ akan memperkuat dinding sel dan akan menghambat hidrolisis yang menyebabkan pemecahan pektin dan pati sehingga dapat menunda pematangan buah. Buah dengan kandungan kalsium yang tinggi memiliki laju respirasi yang lebih lambat sehingga memiliki umur simpan yang lebih lama. Oleh karena itu, perendaman buah dalam larutan kalsium klorida $(\mathrm{CaCl} 2)$ dapat dijadikan salah satu alternatif yang dapat diterapkan untuk penanganan buah pasca panen. 
Bila dilihat dari tinjauan literatur di atas, senyawa kalsium klorida (CaCl2)akan meresap ke dalam buah sehingga meningkatkan kandungan kalsium pada buah tersebut, semakin tinggi konsentrasi larutan kalsium klorida $(\mathrm{CaCl} 2)$, maka semakin tinggi pula kandungan kalsium pada buah dan akan memperlambat laju respirasi dari buah tersebut. Laju respirasi yang lambat akan menghambat pula produksi hormon etilen yang berfungsi untuk menstimulasi pematangan buah. Oleh karena itu,kalsium klorida ( $\mathrm{CaCl} 2)$ dapat memperpanjang umur simpan buah dan mencegah buah cepat membusuk.

Berdasarkan pemaparan latar belakang tersebut, maka peneliti tertarik dan memandang penting untuk melakukan penelitian mengenai "Pengaruh Konsentrasi Kalsium Klorida (CaCl2) dan Lama Perendaman Terhadap Umur Simpan dan Pematangan Buah Mangga (Mangifera indica L.) Cv. Manalagi".

\section{METODE PENELITIAN}

Penelitian ini termasuk jenis penelitian eksperimen (True Experimental Research) dengan pendekatan kuantitatif. Adapun rancangan percobaan yang digunakan dalam penelitian ini adalah Rancangan Acak Lengkap (RAL) dengan ulangan yang sama. Penelitian ini menggunakan metode Rancangan Acak Lengkap (RAL) Faktorial dengan 2 faktor dan 3 ulangan. Faktor pertama yaitu konsentrasi larutan $\mathrm{CaCl} 2$ dengan 5 taraf yaitu: $\mathrm{A} 1=5 \%, \mathrm{~A} 2=$ $10 \%, A 3=20 \%$. Faktor kedua yaitu lama perendaman dengan 4 taraf yaitu: B1= 1 menit, B2= 15 menit, B3= 30 menit, B4= 60 menit. Populasi dalam penelitian ini adalah seluruh buah mangga (Mangifera indica L.) Cv. Manalagi yang ada di Dusun Karang Pansor, Kecamatan Pemenang, Kabupaten Lombok Utara.

Teknik pengambilan sampel dalam penelitian ini menggunakan teknik Sampling Acakan dengan Stratifikasi, yaitu teknik penentuan sampel dengan menggolongkan populasi menurut ciri tertentu untuk keperluan penelitian, penentuan sampel dilakukan secara acakan. Sampel yang digunakan dalam penelitian ini yakni 108 buah mangga (Mangifera indica L.) Cv. Manalagi. Penentuan jumlah sampel berdasarkan jumlah unit 
percobaan sebanyak 12 kombinasi dengan 3 ulangan dan tiap ulangan terdapat 3 buah mangga (Mangifera indica L.) $\mathrm{Cv}$. Manalagi. Jadi secara keseluruhan dibutuhkan $108(12 \times 3 \times 3)$ buah. Jumlah sampel dalam penelitian ini sesuai dengan jumlah sampel yang tertera dalam tabel Krejcie.

\section{HASIL DAN PEMBAHASAN}

\section{Hasil}

Parameter amatan dalam penelitian ini adalah dengan menghitung umur simpan buah mangga (Mangifera indica L) $\mathrm{Cv}$. Manalagi dan menentukan skor warna daging buah berdasarkan indeks warna.

1. Pengaruh konsentrasi kalsium klorida ( $\mathrm{CaCl} 2)$ dan lama perendaman terhadap umur simpan buah mangga (Mangifera indica L.) Cv. Manalagi

\section{Tabel 1}

Data Umur Simpan (Hari) Buah Mangga

(Mangifera indica L) Cv. Manalagi

\begin{tabular}{|c|c|c|c|c|c|c|c|c|c|c|c|c|c|c|}
\hline \multirow{2}{*}{ Ulangan } & \multicolumn{10}{|c|}{ Perlakuan } & $\begin{array}{c}\text { Total } \\
(\mathbf{Y . j})\end{array}$ \\
\cline { 2 - 15 } & $\begin{array}{c}\mathbf{0} \\
\left(\mathbf{a}_{0} \mathbf{b}_{\mathbf{0}}\right)\end{array}$ & $\begin{array}{c}\mathbf{1} \\
\left(\mathbf{a}_{1} \mathbf{b}_{1}\right)\end{array}$ & $\begin{array}{c}\mathbf{2} \\
\left(\mathbf{a}_{1} \mathbf{b}_{2}\right)\end{array}$ & $\begin{array}{c}\mathbf{3} \\
\left(\mathbf{a}_{1} \mathbf{b}_{3}\right)\end{array}$ & $\begin{array}{c}\mathbf{4} \\
\left(\mathbf{a}_{1} \mathbf{b}_{4}\right)\end{array}$ & $\begin{array}{c}\mathbf{5} \\
\left(\mathbf{a}_{2} \mathbf{b}_{1}\right)\end{array}$ & $\begin{array}{c}\mathbf{6} \\
\left(\mathbf{a}_{2} \mathbf{b}_{2}\right)\end{array}$ & $\begin{array}{c}\mathbf{7} \\
\left(\mathbf{a}_{2} \mathbf{b}_{3}\right)\end{array}$ & $\begin{array}{c}\mathbf{8} \\
\left(\mathbf{a}_{2} \mathbf{b}_{4}\right)\end{array}$ & $\begin{array}{c}\mathbf{9} \\
\left(\mathbf{a}_{3} \mathbf{b}_{1}\right)\end{array}$ & $\begin{array}{c}\mathbf{1 0} \\
\left(\mathbf{a}_{3} \mathbf{b}_{2}\right)\end{array}$ & $\begin{array}{c}\mathbf{1 1} \\
\left(\mathbf{a}_{3} \mathbf{b}_{3}\right)\end{array}$ & $\begin{array}{c}\mathbf{1 2} \\
\left(\mathbf{a}_{3} \mathbf{b}_{4}\right)\end{array}$ & \\
\hline 2 & 6 & 9 & 9 & 9 & 9 & 9 & 9 & 9 & 9 & 9 & 9 & 6 & 6 & 108 \\
\hline 3 & 6 & 9 & 9 & 9 & 9 & 9 & 9 & 9 & 9 & 9 & 6 & 6 & 6 & 105 \\
\hline Total (Y.i) & 18 & 27 & 27 & 24 & 27 & 27 & 24 & 27 & 27 & 27 & 24 & 21 & 21 & 321 \\
\hline Rata-rata & 6 & 9 & 9 & 8 & 9 & 9 & 8 & 9 & 9 & 9 & 8 & 7 & 7 & 107 \\
\hline
\end{tabular}


Keterangan:

$\mathrm{a}_{0} \mathrm{~b}_{0} \quad$ : konsentrasi $0 \%$ dan lama perendaman 0 menit

$\mathrm{a}_{1} \mathrm{~b}_{1} \quad$ : konsentrasi $5 \%$ dan lama perendaman 1 menit

$\mathrm{a}_{1} \mathrm{~b}_{2} \quad$ : konsentrasi $5 \%$ dan lama perendaman 15 menit

$\mathrm{a}_{1} \mathrm{~b}_{3} \quad$ : konsentrasi $5 \%$ dan lama perendaman 30 menit

$\mathrm{a}_{1} \mathrm{~b}_{4} \quad$ : konsentrasi $5 \%$ dan lama perendaman 60 menit

$\mathrm{a}_{2} \mathrm{~b}_{1} \quad$ : konsentrasi $10 \%$ dan lama perendaman 1 menit

$\mathrm{a}_{2} \mathrm{~b}_{2} \quad$ : konsentrasi $10 \%$ dan lama perendaman 15 menit

$\mathrm{a}_{2} \mathrm{~b}_{3} \quad$ : konsentrasi $10 \%$ dan lama perendaman 30 menit

$\mathrm{a}_{2} \mathrm{~b}_{4} \quad$ : konsentrasi $10 \%$ dan lama perendaman 60 menit

$\mathrm{a}_{3} \mathrm{~b}_{1} \quad$ : konsentrasi $20 \%$ dan lama perendaman 1 menit

$\mathrm{a}_{3} \mathrm{~b}_{2} \quad$ : konsentrasi $20 \%$ dan lama perendaman 15 menit

$\mathrm{a}_{3} \mathrm{~b}_{3} \quad$ : konsentrasi $20 \%$ dan lama perendaman 30 menit

$\mathrm{a}_{3} \mathrm{~b}_{4} \quad$ : konsentrasi $20 \%$ dan lama perendaman 60 menit

\section{Tabel 2}

Data Hasil Sidik Ragam Umur Simpan Buah Mangga (Mangifera indica L) Cv. Manalagi

\begin{tabular}{|l|c|c|c|c|c|c|}
\hline \multirow{2}{*}{$\begin{array}{c}\text { Sumber } \\
\text { keragaman }\end{array}$} & Db & JK & KT & \multirow{2}{*}{ F hit } & \multicolumn{2}{|c|}{ F tabel } \\
\cline { 4 - 7 } & & & & & $5 \%$ & $1 \%$ \\
\hline Perlakuan & 11 & 20.8 & 1.89 & & & \\
\hline $\mathrm{A}$ & 2 & 8 & 4 & $3.2^{\mathrm{ns}}$ & 3.40 & 5.61 \\
\hline $\mathrm{B}$ & 3 & 4.8 & 1.6 & $1.28^{\mathrm{ns}}$ & 3.01 & 4.72 \\
\hline $\mathrm{AB}$ & 6 & 8 & 1.33 & $1.06^{\mathrm{ns}}$ & 2.51 & 3.67 \\
\hline Galat & 24 & 30 & 1.25 & & & \\
\hline Total & 35 & 50.8 & & & & \\
\hline
\end{tabular}

Berdasarkan Tabel 2 di atas dapat diketahui bahwa pada semua perlakuan, yakni perlakuan A (konsentrasi kalsium klorida), perlakuan $\mathrm{B}$ (lama perendaman) dan perlakuan $\mathrm{AB}$ (kombinasi antara perlakuan $\mathrm{A}$ dan $\mathrm{B}$ ) diperoleh hasil $\mathrm{F}$ hitung $\leq \mathrm{F}$ tabel (ditandai ns) yang berarti perbedaan diantara semua perlakuan dikatakan tidak nyata (non signifikan)sehingga $\mathrm{H}_{0}$ diterima dan Ha ditolak. 


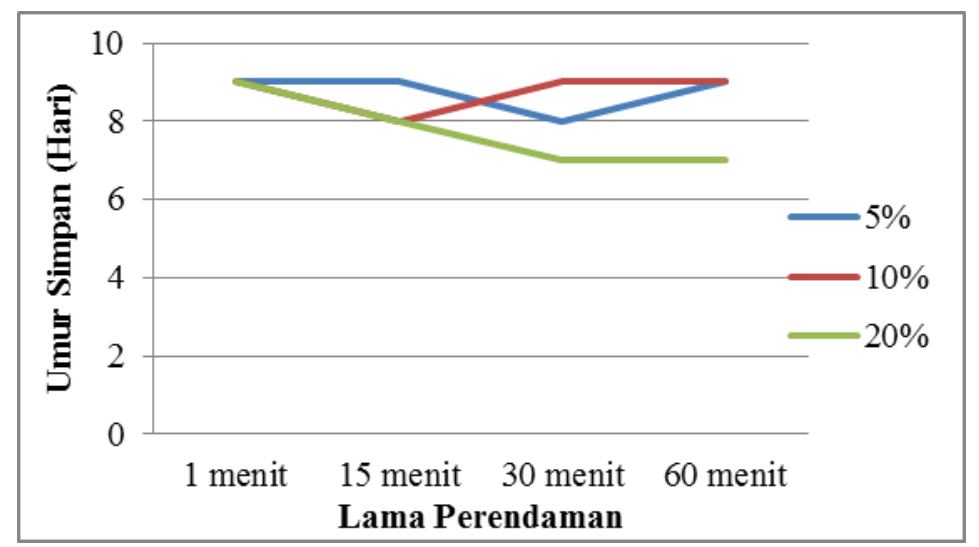

Gambar 1. Grafik Rata-Rata Umur Simpan Buah Mangga (Mangifera indica L) Cv. Manalagi

2. Pengaruh konsentrasi kalsium klorida $(\mathrm{CaCl} 2)$ dan lama perendaman terhadap pematangan buah mangga (Mangifera indica L.) Cv. Manalagi.

\section{Tabel 3}

Data Hasil Kematangan Buah Mangga (Mangifera indica L)

Cv.Manalagi Berdasarkan Skor Warna Daging Buah

Pada Indeks Warna

\begin{tabular}{|c|c|c|c|c|c|c|c|c|c|c|c|c|c|c|c|}
\hline \multirow[b]{2}{*}{ Ulangan } & \multicolumn{14}{|c|}{ Perlakuan } & \multirow{2}{*}{$\begin{array}{l}\text { Total } \\
\text { (Y.j) }\end{array}$} \\
\hline & $\begin{array}{c}\mathbf{0} \\
\left(\mathbf{a}_{0} \mathbf{b}_{0}\right)\end{array}$ & $\left.\begin{array}{c}1 \\
\left(a_{1} b_{1}\right)\end{array}\right)$ & $\begin{array}{r}2 \\
\mathbf{a}_{1} \mathbf{b}\end{array}$ & $\begin{array}{r}3 \\
\left(\mathbf{a}_{1} \mathbf{b}_{3}\right.\end{array}$ & $\begin{array}{c}4 \\
\left(a_{1} \mathbf{b}_{4}\right)\end{array}$ & $\left.\begin{array}{c}5 \\
\left(\mathbf{a}_{2} \mathbf{b}_{1}\right.\end{array}\right]$ & $\begin{array}{r}6 \\
\mathbf{a}_{2} \mathbf{b}\end{array}$ & $a^{7}$ & $\begin{array}{l}7 \\
\left.b_{3}\right)(\end{array}$ & $\begin{array}{c}8 \\
\mathbf{a} \\
\left.\mathbf{a}_{2} \mathbf{b}_{4}\right)\end{array}$ & $\begin{array}{c}9 \\
\left(a_{3} b_{1}\right.\end{array}$ & $\mid \begin{array}{l}10 \\
\left(\begin{array}{l}10 \\
b_{3}\end{array}\right)\end{array}$ & $\begin{array}{c}11 \\
\left(a_{3} b_{3}\right)\end{array}$ & $\begin{array}{c}12 \\
\left(\mathbf{a}_{3} \mathbf{b}_{4}\right)\end{array}$ & \\
\hline 1 & 6 & 5 & 6 & 5 & 6 & 6 & 6 & & 6 & 6 & 6 & 6 & 6 & 6 & 76 \\
\hline 2 & 6 & 6 & 6 & 6 & 6 & 6 & 6 & & 6 & 6 & 6 & 6 & 6 & 6 & 78 \\
\hline 3 & 6 & 5 & 6 & 6 & 6 & 5 & 6 & & 6 & 6 & 6 & 5 & 6 & 6 & 75 \\
\hline Total (Y.i) & 8 & 16 & 18 & 17 & 18 & 17 & 8 & & 18 & 18 & 8 & 7 & 18 & 8 & 229 \\
\hline Rata-rata & 6 & 5.33 & 6 & 5.67 & 6 & 5.67 & 6 & & 6 & 6 & 6 & 5.67 & 6 & 6 & 76.33 \\
\hline
\end{tabular}


Keterangan:

$\mathrm{a}_{0} \mathrm{~b}_{0} \quad$ : konsentrasi $0 \%$ dan lama perendaman 0 menit

$\mathrm{a}_{1} \mathrm{~b}_{1} \quad$ : konsentrasi $5 \%$ dan lama perendaman 1 menit

$\mathrm{a}_{1} \mathrm{~b}_{2} \quad$ : konsentrasi $5 \%$ dan lama perendaman 15 menit

$\mathrm{a}_{1} \mathrm{~b}_{3} \quad$ : konsentrasi 5\% dan lama perendaman 30 menit

$\mathrm{a}_{1} \mathrm{~b}_{4} \quad$ : konsentrasi 5\% dan lama perendaman 60 menit

$\mathrm{a}_{2} \mathrm{~b}_{1} \quad$ : konsentrasi $10 \%$ dan lama perendaman 1 menit

$\mathrm{a}_{2} \mathrm{~b}_{2} \quad$ : konsentrasi $10 \%$ dan lama perendaman 15 menit

$\mathrm{a}_{2} \mathrm{~b}_{3} \quad$ : konsentrasi $10 \%$ dan lama perendaman 30 menit

$\mathrm{a}_{2} \mathrm{~b}_{4} \quad$ : konsentrasi $10 \%$ dan lama perendaman 60 menit

$\mathrm{a}_{3} \mathrm{~b}_{1} \quad$ : konsentrasi $20 \%$ dan lama perendaman 1 menit

$\mathrm{a}_{3} \mathrm{~b}_{2} \quad$ : konsentrasi $20 \%$ dan lama perendaman 15 menit

$\mathrm{a}_{3} \mathrm{~b}_{3}$ : konsentrasi $20 \%$ dan lama perendaman 30 menit

azb4 : konsentrasi $20 \%$ dan lama perendaman 60 menit

\section{Tabel 4}

Data Hasil Sidik Ragam Kematangan Buah Mangga (Mangifera indica L) Cv. Manalagi Berdasarkan Skor Warna Daging Buah Pada Indeks Warna

\begin{tabular}{|l|c|c|c|c|c|c|}
\hline \multirow{2}{*}{$\begin{array}{c}\text { Sumber } \\
\text { keragaman }\end{array}$} & $\mathrm{Db}$ & $\mathrm{JK}$ & $\mathrm{K}$ & \multirow{2}{*}{$\mathrm{F}$ hit } & \multicolumn{2}{|c|}{ F tabel } \\
\cline { 5 - 7 } & & & & & $5 \%$ & $1 \%$ \\
\hline Perlakuan & 11 & 1.6 & 0.14 & & & \\
\hline $\mathrm{A}$ & 2 & 0.2 & 0.1 & $0.91^{\mathrm{ns}}$ & 3.40 & 5.61 \\
\hline $\mathrm{B}$ & 3 & 0.5 & 0.17 & $1.54^{\mathrm{ns}}$ & 3.01 & 4.72 \\
\hline $\mathrm{AB}$ & 6 & 0.9 & 0.15 & $1.36^{\mathrm{ns}}$ & 2.51 & 3.67 \\
\hline Galat & 24 & 2.7 & 0.11 & & & \\
\hline Total & 35 & 4.3 & & & & \\
\hline
\end{tabular}

Berdasarkan Tabel 4 di atas dapat diketahui bahwa pada semua perlakuan, yakni perlakuan A (konsentrasi kalsium klorida), perlakuan $B$ (lama perendaman) dan perlakuan $A B$ (kombinasi antara perlakuan $\mathrm{A}$ dan $\mathrm{B}$ ) diperoleh hasil $\mathrm{F}$ hitung $\leq \mathrm{F}$ tabel (ditandai ns) yang berarti perbedaan diantara semua 
perlakuan dikatakan tidak nyata (non signifikan) sehingga $\mathrm{H}_{0}$ diterima dan Ha ditolak.

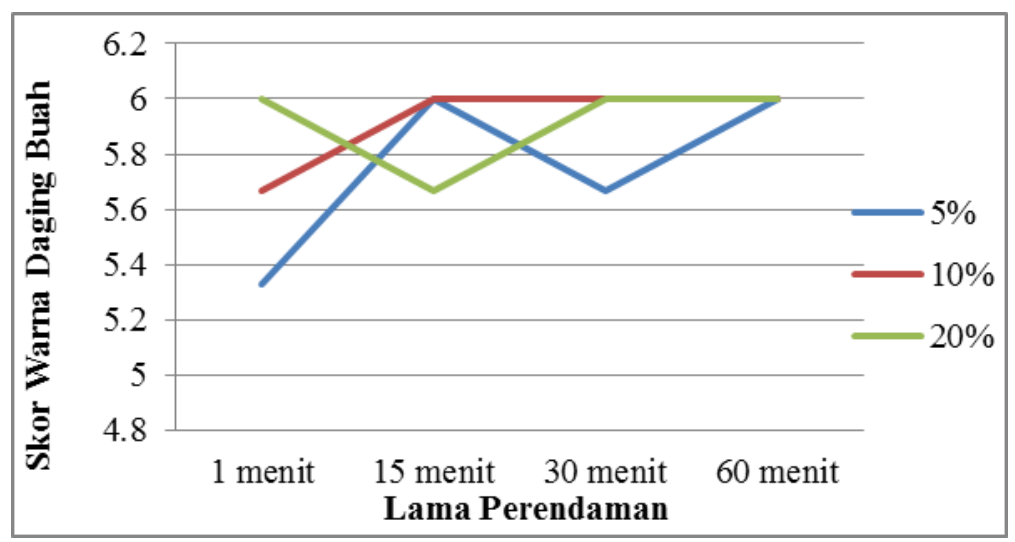

Gambar 2. Grafik Rata-Rata Kematangan Buah Mangga (Mangifera indica L) Cv. Manalagi

Berdasarkan hasil Analisis of Variance tentang pengaruh konsentrasi kalsium klorida $\left(\mathrm{CaCl}_{2}\right)$ terhadap umur simpan dan pematangan buah mangga (Mangifera indica L) Cv. Manalagi tidak terdapat pengaruh yang nyata pada semua perlakuan sehingga tidak dilanjutkan dengan uji lanjut BNJ (Beda Nyata Jujur) taraf signifikansi 5\%. Terkait dengan hal di atas, Sudjana (2004:53), menjelaskan bahwa sebagai salah satu bagian dari fungsi-fungsi manajerial, maka posisi fungsi penggerakan dalam rangkaian fungsi manajemen/organisasi apabila diilustrasikan dalam sebuah gambar akan tampak sebagai berikut;

\section{Pembahasan}

1. Pengaruh konsentrasi kalsium klorida $\left(\mathrm{CaCl}_{2}\right)$ dan lama perendaman terhadap umur simpan buah mangga (Mangifera indica L.) Cv. Manalagi

Data hasil penelitian tentang pengaruh konsentrasi kalsium klorida $\left(\mathrm{CaCl}_{2}\right)$ dan lama perendaman terhadap umur simpan buah mangga (Mangifera indica L.) Cv. Manalagi diperoleh berdasarkan waktu yang dibutuhkan buah hingga mencapai tingkat kematangan optimum. Berdasarkan hasil 
penelitian, perendaman buah mangga (Mangifera indica L.) $\mathrm{Cv}$. Manalagi dalam larutan $\mathrm{CaCl}_{2}$ dengan konsentrasi $5 \%$ dan $10 \%$ menunjukkan pola kuadratik, yang berarti variasi lama perendaman buah dalam larutan $\mathrm{CaCl}_{2}$ dengan konsentrasi 5 dan $10 \%$ tidak berbeda nyata dengan umur simpan yang relatif sama. Hal ini menunjukkan bahwa perendaman buah dalam larutan $\mathrm{CaCl}_{2}$ dengan konsentrasi 5 dan 10\% tidak dapat memperpanjang umur simpan buah. Sedangkan perendaman buah dalam larutan $\mathrm{CaCl}_{2}$ dengan konsentrasi $20 \%$ menunjukkan pola menurun, yang berarti semakin lama buah direndam dalam larutan $\mathrm{CaCl}_{2}$ dengan konsentrasi $20 \%$, umur simpan buah tersebut semakin berkurang.

Data hasil penelitian tentang pengaruh konsentrasi kalsium klorida $\left(\mathrm{CaCl}_{2}\right)$ dan lama perendaman terhadap umur simpan buah mangga (Mangifera indica L.) Cv. Manalagi menunjukkan tidak adanya pengaruh yang signifikan pada setiap perlakuan. Hal ini dapat dilihat dari data tersebut dengan hasil $\mathrm{F}$ hitung $\leq$ Ftabel $=$ Ha ditolak.

Tidak adanya pengaruh konsentrasi kalsium klorida $\left(\mathrm{CaCl}_{2}\right)$ dan lama perendaman terhadap umur simpan buah mangga (Mangifera indica L.) Cv. Manalagi disebabkan oleh beberapa faktor diantaranya kemampuan kalsium klorida $\left(\mathrm{CaCl}_{2}\right)$ untuk meresap ke dalam daging buah, waktu pemetikan buah dan tingkat kematangan buah yang digunakan.

Kalsium klorida $\left(\mathrm{CaCl}_{2}\right)$ memiliki kemampuan dalam menstabilkan dinding sel dan membran sel.Kalsium dapat menghambat proses pemasakan dan memperpanjang masa simpan buahdengan menghambat produksi etilen tanpa mempengaruhi $\mathrm{pH}$, padatan terlarut total, maupun warna buah.Kemampuan kalsium klorida $\left(\mathrm{CaCl}_{2}\right)$ meresap ke dalam daging buah berbeda-beda pada beberapa jenis buah. Hal ini dapat dikaitkan dengan penelitian yang dilakukan oleh Elmaulida Nur Faiqoh, bahwa Pemberian konsentrasi kalsium klorida $\left(\mathrm{CaCl}_{2}\right)$ yang berbeda berpengaruh terhadap kualitas dan kuantitas buah naga super merah (Hylocereus 
costaricensis). Kosentrasi kalsium klorida 6\% merupakan konsentrasi terbaik karena mampu menekan proses pematangan dan mempertahankan kualitas buah (tekstur, kandungan vitamin $\mathrm{C}$, warna dan umur simpan) dan kuantitas buah (susut bobot) sampai hari ke-12.

Selain itu, penelitian yang dilakukan oleh Megasari Ramadani menunjukkan bahwa adanya pengaruh interaksi konsentrasi dan lama waktu perendaman dalam larutan kalsium klorida $\left(\mathrm{CaCl}_{2}\right)$ terhadap kelunakan buah pepaya selama masa penyimpanan. Buah dengan konsentrasi $6 \%$ dan 8\% pada perendaman selama 45 menit dan 60 menit memiliki skor 3 (lunak) pada hari ke-9 dan memiliki skor 4 (sangat lunak) pada hari ke-12. Dalam penelitian ini diperoleh hasil yang menunjukkan bahwa tidak ada pengaruh interaksi konsentrasi dan lama waktu perendaman dalam larutan kalsium klorida $\left(\mathrm{CaCl}_{2}\right)$ terhadap umur simpan buah (Mangifera indica L) Cv. Manalagi, hal ini dapat disesabkan oleh tingkat ketebalan daging buah sehingga mempengaruhi daya serap larutan kalsium klorida $\left(\mathrm{CaCl}_{2}\right)$.

Mangga siap dipanen ketika di pohon sudah terlihat satu atau dua buah yang masak. Waktu yang tepat untuk memanen buah mangga, termasuk buah mangga manalagi adalah pada saat buah tersebut sudah tua, tetapi masih dalam keadaan tekstur buah yang keras. Sebagaimana yang dinyatakan oleh Pracaya (2011), bahwa jangan menunggu sampai buah masak untuk melakukan pemanenan, karena akan ada banyak buah yang rusak. Sebaiknya, pemanenan mangga dilakukan ketika buahnya masih keras, namun sudah tua. Buah yang sudah tua, kecepatan respirasinya akan bertambah sehingga laju pematangannya berlangsung cepat.

Dalam penelitian ini, buah yang dipetik atau dipanen merupakan buah mangga (Mangifera indica L.) Cv. Manalagi yang sudah tua sesuai dengan krteria-kriteria tertentu. Akan tetapi, pemetikan buah dilakukan sehari sebelum pemberian perlakuan berupa perendaman dalam larutan kalsium klorida $\left(\mathrm{CaCl}_{2}\right)$, sehingga buah telah memasuki proses pematangan secara fisiologis selama proses penyimpanan. Hal ini akan 
mempengaruhi pula umur simpan buah hingga mencapai tingkat kematangan optimum.

\section{Pengaruh konsentrasi kalsium klorida $\left(\mathrm{CaCl}_{2}\right)$ dan lama perendaman terhadap umur simpan buah mangga (Mangifera indica L.) Cv. Manalagi}

Data hasil penelitian tentang pengaruh konsentrasi kalsium klorida $\left(\mathrm{CaCl}_{2}\right)$ dan lama perendaman terhadap pematangan buah mangga (Mangifera indica L.) Cv. Manalagi diperoleh berdasarkan skor warna daging buah pada indeks warna. Pengamatan terhadap kematangan buah mangga (Mangifera indica L) Cv. Manalagi ditentukan berdasarkan skor warna daging buahnya (mesocarpium) dengan struktur yang tebal, berdaging dan berserat.

Berdasarkan hasil penelitian, perendaman buah mangga (Mangifera indica L.) $\mathrm{Cv}$. Manalagi dalam larutan $\mathrm{CaCl}_{2}$ dengan konsentrasi 5\%, 10\% dan 20\% menunjukkan pola kuadratik (non linier), yang berarti variasi lama perendaman buah dalam larutan $\mathrm{CaCl}_{2}$ dengan konsentrasi 5 dan $10 \%$ tidak berbeda nyata dengan skor warna daging buah yang relatif sama. Hal ini menunjukkan bahwa perendaman buah dalam larutan $\mathrm{CaCl}_{2}$ dengan konsentrasi 5 dan 10\% tidak dapat menghambat pematangan buah.

Selama penyimpanan pada suhu ruang, daging buah mangga memperlihatkan warna kuning yang semakin intensif. Skor warna daging buah terendah didapatkan pada mangga yang direndam dalam larutan $5 \% \mathrm{CaCl}_{2}$ selama 1 menit yakni 5,33. Hasil terendah ini dapat dipengaruhi oleh waktu yang diperlukan $\mathrm{CaCl}_{2}$ untuk meresap ke dalam buah. Hal ini berkaitan dengan pernyataan Muchtadi bahwa kalsium mempunyai sifat mudah larut dalam air, dengan adanya kalsium klorida $\left(\mathrm{CaCl}_{2}\right)$ dalam larutan, maka ion $\mathrm{Ca} 2+$ akan memperkuat dinding sel dan akan menghambat hidrolisis yang menyebabkan pemecahan pektin dan pati sehingga dapat menunda pematangan buah. Pada perlakuan kontrol (tanpa perendaman dalam larutan kalsium klorida) digunakan 9 buah 
mangga (Mangifera indica L) Cv. Manalagi dan secara keseluruhan mempunyai skor warna daging buah yakni 6 yang berarti telah mencapai tingkat kematangan optimum.

Data hasil penelitian tentang pengaruh konsentrasi kalsium klorida $\left(\mathrm{CaCl}_{2}\right)$ dan lama perendaman terhadap pematangan buah mangga (Mangifera indica L.) Cv. Manalagi menunjukkan tidak adanya pengaruh yang signifikan pada setiap perlakuan. Hal ini dapat dilihat dari data tersebut dengan hasil $\mathrm{F}$ hitung $\leq$ Ftabel $=$ Ha ditolak.

Tidak adanya pengaruh konsentrasi kalsium klorida $\left(\mathrm{CaCl}_{2}\right)$ dan lama perendaman terhadap pematangan buah mangga (Mangifera indica L.) Cv. Manalagi disebabkan oleh beberapa faktor diantaranya jenis buah, tingkat kematangan buah yang digunakan dan suhu ruang penyimpanan. Buah mangga(Mangifera indica L.) Cv. Manalagi termasuk buah klimaterik, yaitu buah yang mengalami kenaikan respirasi setelah dipanen sehingga buah dapat matang sempurna dan menuju ke proses penuaan. Sebagaimana yang dikemukakan oleh Kamarani (1986) bahwa buah klimaterik menunjukkan peningkatan yang besar dalam laju produksi karbondioksida $\left(\mathrm{CO}_{2}\right)$ dan etilen $\left(\mathrm{C}_{2} \mathrm{H}_{4}\right)$ bersamaan dengan terjadinya pemasakan. Sedangkan non-klimaterik tidak menunjukkan perubahan, umumnya laju produksi karbondioksida $\left(\mathrm{CO}_{2}\right)$ dan etilen $\left(\mathrm{C}_{2} \mathrm{H}_{4}\right)$ selama pemasakan sangat rendah.Buah klimaterik mengalami laju pematangan yang lebih cepat dibandingkan dengan buah non-klimaterik. Suhu ruang penyimpanan buah juga berpengaruh terhadap proses pematangannya. Sebagaimana yang dinyatakan oleh AAK bahwa apabila buah mangga disimpan pada tempat penyimpanan dengan suhu 18$21{ }^{0} \mathrm{C}$, buah akan masak dalam waktu 4 sampai 7 hari. Sedangkan buah mangga yang disimpan pada suhu 9-10 ${ }^{\circ} \mathrm{C}$ dapat tahan lebih kurang 4 sampai 9 hari.

\section{KESIMPULAN}

Berdasarkan pembahasan dan analisis data dalam penelitian ini, dapat disimpulkan bahwatidak ada pengaruh 
konsentrasi kalsium klorida $\left(\mathrm{CaCl}_{2}\right)$ dan lama perendaman terhadap umur simpan dan pematangan buah mangga (Mangifera indica L) $\mathrm{Cv}$. Manalagi. Hal ini dapat dilihat dari hasil analisis data di mana $\mathrm{F}$ Hitung $\leq \mathrm{F}$ Tabel sehingga Ha ditolak.

\section{DAFTAR PUSTAKA}

AAK. 1991. Mangga. Yogyakarta: Kanisius.

Anny, Thuraidah. 2006. Pengaruh Kalsium Klorida ( $\left.\mathrm{CaCl}_{2}\right)$ dan Lama Penyimpanan Terhadap Kadar Vitamin C Anggur (Vitisvinifera). Poltekes Banjarmasin.

Atikatuz Zahrok, Pengaruh Perlakuan Calcium Chlorida ( $\left.\mathrm{CaCl}_{2}\right)$ Dalam Berbagai Konsentrasi Terhadap Kandungan Vitamin A dan Vitamin C Pada Mangga Arumanais (Mangifera indica L.), PRO SIDING SEMNAS SAINS \& ENTREPRENEURSHIP II, (Agustus, 2015).

Elmaulida Nur Faiqoh, Pengaruh Konsentrasi dan Lama Perendaman Dalam $\mathrm{CaCl}_{2}$ (Kalsium Klorida) Terhadap Kualitas dan Kuantitas Buah Naga Super Merah (Hylocereus costaricensis). Universitas Islam Negeri Maulana Malik Ibrahim Malang.

Emzir. 2011. Metodologi Penelitian Pendidikan Kuantitatif dan Kualitatif.Jakarta: Rajawali Pers, 2011.

Gardner, Franklin P.1991. Fisiologi Tanaman Budidaya. Jakarta: Universitas Indonesia Press.

Ita Setiani Rahmawati, Pengaruh Perlakuan Konsentrasi Kalsium Klorida $\left(\mathrm{CaCl}_{2}\right)$ dan Lama Penyimpanan terhadap Kadar Asam Askorbat Buah Tomat (Lycopersicum esculentum Mill.), Buletin Anatomi dan Fisiolog, No. 1, Vol. XIX, (Maret, 2011). 
Kamarani. 1986. Fisiologi Pasca Panen. Yogyakarta: Gadjah Mada University Press.

Kusriningrum R.S. 2010. Perancangan Percobaan. Surabaya: Airlangga University Press.

Marshalina et al, Klasifikasi Buah Mangga Berdasarkan Bentuk dan Warna dengan Metode Curvelet, (Tugas Akhir, 2012).

Megasari Ramadani et al, Penggunaan Larutan Kalsium Klorida $\left(\mathrm{CaCl}_{2}\right)$ dalam Menunda Pematangan Buah Pepaya (Carica papaya L.), Jurnal Protobiont, No. 3, Vol. 2, (Mei, 2013).

Nasution. 2014. Metode Research (Penelitian Ilmiah). Jakarta: Bumi Aksara.

Nazir. 2005. Metode Penelitian. Bogor: Ghalia Indonesia.

Nurjanah Puspa Salatin, Perbanyakan Tanaman Mangga (Mangifera indica) dengan Cara Cangkok, (Tugas Akhir, 2002), Universitas Sebelas Maret Surakarta.

Pracaya. 2011. Bertanam Mangga. Jakarta: Penebar Swadaya.

Tim Bina Karya Tani. 2008. Pedoman Bertanam Mangga. Bandung: Yrama Widya.

Umar, Husein. 2011. Metode Penelitian Untuk Skripsi dan Tesis Bisnis.Jakarta: Rajawali Pers. 